it should split public opinion into factious opposition. What advocates of world government wish can be obtained, where possible of attainment, more easily through the development and strengthening of UNO than by scrapping UNO and building anew. It is a very common error to say that the only alternatives are sovereignty or no sovereignty. Sovereignty, certainly in the practice of today, is not an absolute matter, but a very relative one. It may be compared to individual liberty, which is never regarded as absolute freedom of action. Sovereignty likewise will be earnestly maintained, but sovereignty also is being progressively restricted. This process has been going on for years, and UNO, weak as it is, has added further restrictions upon sovereignty. This process should be continued, and can be, but it would not be possible to travel the whole distance in one leap. Few persons are satisfied with UNO as it now stands, and many believe that public opinion would have approved more authority for it than timorous Senators and statesmen were willing to confer upon it. With the added weight of fear of the atomic bomb upon public opinion there is little doubt that the American people would, with adequate leadership, approve various steps moving the UNO in the direction of world government, but it is very much to be doubted whether they would be willing to scrap UNO and again go through the travail of creating a new system. That would be a dangerous risk to take.

Clyde Eagleton

\title{
THE ALTERNATIVE TO APPEASEMENT
}

Once again the more important states of the world and their governments and their peoples are being confronted by the question of whether they shall seek international peace and justice by a process of appeasement. To some degree all states are placed in this position but it is states with more power to determine the course of international affairs and greater responsibility therefor, in a vague sense, and, conversely, with greater interests at stake, which are more gravely affected. It is also true that this question-that of trying to forestall recourse to violence and satisfy the demands of justice by concessions to national demands-is an ever present issue in international affairs, but the issue becomes more acute at certain times when some one or more states thake especially drastic demands, accompanied by especially dangerous threats, express or implied. Such a situation developed in the world between 1922 and 1941, Italy, Japan, and Germany being the leading figures in the action, and it is widely felt that as a result of Russian policies and initiatives a similar situation confronts the world today.

It will be denied by many critics of appeasement that there is involved any question of satisfying just demands, or of doing justice beyond preserving peace, in such situations. This would seem to be an untenable, and also a very dangerous, attitude. In any such situation the demands of the complaining and aggressive (but not yet aggressor) states almost invariably contain a greater or less amount, or more or fewer items, of justice. Japan 
had just complaints against China in 1931 and 1937, Italy just complaints against Ethiopia in 1934-1935, and Germany just complaints against Poland and other countries in 1939. Indeed it is in part the more or less completely negative non possumus attitude of the other states which renders the demands of the aggressive state so intransigeant. The real objection to his demands often lies not in their injustice but precisely in their intransigeance and more particularly still in his unwillingness to seek satisfaction through the processes of inquiry, discussion, and consent and thus submit his demands to appraisal as to their justifiability. Opponents of appeasement often fall into a similar error on the other side and practically repudiate the basic principle of revision in its entirety.

This is a problem of human relations, behavior, or tactics, in all walks of life, but it is a peculiarly international problem and has been recognized as such for some time. It is even a problem of international law if enforcement of international rights and obligations is, as is often argued, a question of international law itself. It is closely related to the problem of how best to advance the development of international institutions, which has recently been given sharp attention by various students. ${ }^{1}$ The question is peculiarly important in the international field because of the relatively limited extent to which substantive rights and procedure for the vindication of those rights are defined and provided by international law; this makes negotiation and manoeuvering and tactics doubly important in comparison with their status in the more fully regulated national field.

The thought back of an appeasement policy is obvious. Preservation of peace is of paramount importance, it is argued; therefore such concessions should be made, within reason, as will satisfy the demands of aggressive states. In absence of adequate international community facilities for adjudicating upon their rights and enforcing the law, including the obligation to refrain from aggression (assuming that there is such an obligation), and in view of the dangers involved in attempting to carry out such a program, it is felt to be better to be conciliatory and conceding. Today the idea that preservation of unity among the Great Powers is essential to the maintenance of peace is added to the argument.

The weakness of such a program is also obvious (the obscure and perplexing problems arise later). Justice is forgotten, in carrying out such a program, in the interest of immediate peace, although peace cannot be stable if based on injustice, and the qualification "within reason" is forgotten and the making of concessions becomes a headlong capitulation. The demands of the aggressive state being based largely on mere interest rather than on law, concessions do not quiet the issue but seem to be a sign of weakness and encourage further demands. The attempt to buy off the aggressive state by concessions, loans, or other favors, is futile. Such grants encourage other states to make similar demands, if they believe that

1 This Journar, Vol. 39 (1945), p. 547, note 4. 
they can succeed in such a venture, or, conversely, they discourage victimized states from standing up for their rights if they feel powerless to contest a case. And it is precisely among the Great Powers that the greatest vigilance is required in this respect. In these ways the international situation is undermined morally or psychologically and even juridically. The result is likely to constitute not only a gross sacrifice of justice but also a general collapse of international morale, leading to that very outbreak of war which it was sought to avoid, especially if the aggressive state is willing, as is likely to be the case, to go that far.

The real difficulty arises when it is asked what is the proper alternative to appeasement as a method for dealing with aggressive demands. Two or three possible techniques for meeting the situation may be considered. One method frankly advanced is preventive war, another is that of adopting substantially the methods and manner of the aggressive state. A third may better be analyzed and described when we come to it than sharply labelled in advance.

Advocacy of preventive war in such a situation seems unduly extreme, unnecessarily extravagant, almost a counsel of despair, as it at once plunges into one of the two results sought to be avoided, with all its disastrous consequences and uncertainties. If the states resisting impending aggression could be sure of quick and effective results there would be much to be said for the action in question; it could well take on the character of international police action-if well founded in right and general international approval; certainly if war is inevitable (which is never certain) preventive action is immeasurably superior to merely waiting for the aggressor to choose his own occasion while allowing one's own powers to dwindle in the meantime. But although the vices of preventive war have been exaggerated by the pacifists, and its possible values unduly ignored, it obviously constitutes a desperate expedient, one to be adopted only if there is no other alternative available; it is the typical hasty "solution" proposed by the military "mind."

In a reaction against or away from appeasement another "strong" or "firm" or "hard" technique is at times put forward " which, while it expressly repudiates war as a possibility, certainly seems to lie on the same side of the psychological and political spectrum. The bold demands of the aggressive state are to be matched with equally bold statements by those who oppose him. Complaint is to be met with complaint, if circumstances warrant, and even threats are to be met by an attitude which refuses to be intimidated and which clearly by implication threatens resistance. And all thought of appeasement, justified or unjustified, would disappear upan the adoption of such an attitude.

The basic idea underlying such a stand is sound and so are one or two

${ }^{2}$ Addresses of Senator Vandenberg and Secretary of State Byrnes on February 27 and 28 and that of Mr. Churchill on March 5, 1946: The New York Times, February 28 and March 1 and $6,1946$. 
subordinate considerations involved. It is equally true, however, that certain qualifications and cautions are necessary.

It is thus wholly wise and sound to repudiate unjustified and shortsighted appeasement and to stand up for what is right. And in so far as the aggressive state is bluffing or counting on obtaining what it wants merely by the effect of strong words, replying in kind may be just the thing needed. Finally, the general moral, psychological, or political effect of courageous leadership in maintaining the principles of international law and order should count for something here.

On the other hand, if such a change of attitude means merely to indulge in a contest in loud shouting or aggressive action, it can be exceedingly dangerous, especially if accompanied by the fatal non-possumus attitude mentioned earlier. If the aggressive state should not have been bluffing the effect may be to upset the applecart and to do so without careful calculation of advantage as to time and other factors. This is bound to be disastrous if the tactic of strong words and firm stands is adopted under the illusion that it will necessarily be sufficient, because of the moral position of the defender of international peace and order, for the aggressive state will certainly not defer to any such considerations. If a policy of strong words is to be adopted it must be backed up by willingness and ability to defend the law by force if need be.

What then is the proper alternative to appeasement? Is there no sound compromise between the latter on one side and, on the other, preventive war or the less immediate but also extremely dangerous technique just considered? It hardly seems that the wise course to be pursued in such circumstances need be either undiscoverable or unattainable. Men have been struggling with this problem for six thousand years of recorded history and for many more thousands of years of unrecorded history. It is a perennial problem, and it will not be entirely eliminated by the establishment of a world state, a system of world law, and even facilities for its execution; it is the generic problem of maintaining law and justice and the general welfare by wise tactics vis- $d$-vis potentially anti-social action.

Abandonment of unsound appeasement, for the reasons recited, is obviously the first step to be taken along the road to both peace and justice; the arguments supporting this conclusion do not need to be repeated here. This must include a resolute refusal to give any aid, economic or other, so long as the aggressive state maintains its unreasonable demands or its antisocial actions, or which can aid it in these matters. Repudiation of any intention of preventive war is almost equally important, especially if the aggressive state labors under a morbid fear in this respect; such a repudiation may not be entirely convincing to the latter but if, as is almost certainly the case, this position is sincerely taken it should be possible by fullest publicity and repetition and detailed elaboration to make it so. Next a firm but a quiet and considerate attitude must be taken on the issues at stake- 
absolutely firm but scrupulously dispassionate and reasonable; this must be supplemented by a constant readiness for frankness, understanding, agreement, and even coöperation in removing misunderstanding and causes of strife. This must all be backed up by equally unostentatious but unconcealed maintenance of economic and military power-rehabilitation of that power if it has been allowed to degenerate. Measures of appeasement may safely be undertaken if it is clearly stipulated that no rights are waived in the process, and adequate precautions taken against sharp practices on the part of the adversary. And when confronted by physical faits accomplis the choice must be made between being content with public protest, plus refusal of coöperation, even approaching measures of non-intercourse or boycott, and general hostile physical action if the situation justifies it.

Finally, and most important of all, emphasis must be shifted from the concrete cases or issues at stake to the question of their mode of treatment or settlement. Wrangling over specific items is ordinarily the cardinal weakness alike of the position of the aggressive state and of that of the defenders of international law and world peace, as suggested earlier in this discussion. They assert and deny title to or possession of a certain piece of territory, e.g., when they-that is, the defenders-should throw all their weight behind the demand for methods of rational and pacific settlement (inquiry, discussion, agreement or/and adjudication). Insisting on orderly processes of settlement is in the main the keynote of this whole problem, or its solution. It is far more difficult for the aggressive state to meet this proposal than concrete opposition to his concrete demands or action, and this is the only thing which the defenders have a right to ask, a priori, in any case. The proper alternative to appeasement is not to match aggressiveness by war or bellicosity but to substitute for appeasement quiet but unflinching insistence on orderly processes of settlement-accompanied by genuine willingness to make changes when this process indicates that they should be made, but also by maintenance of force for use in case of need. Even this will not necessarily accomplish the result desired-maintenance of international law and peace-but it has a far better chance of attaining that end then either appeasement or violence and if it breaks down the position of the aggressor state must be far weaker morally, politically, and hence from a physical standpoint also. ${ }^{3}$

\section{Pitman B. Potter}

\section{DUE PROCESS AND INTERNATIONAL LAW}

In a six to two decision the United States Supreme Court recently sustained the decision of a Military Commission appointed by General MacArthur in the Philippines sentencing General Yamashita for failure to prevent

- Since this was written Mr. Dulles, Senator Connolly, and former Secretary Hull have suggested what they believed to be appropriate programs to be followed in the circumstances: The New York Times, March 2, 12 (p. 5), and 13, 1946. 